\title{
Lengthz-Weight Relationship and Condition Factor of Coelotilapia joka (Thys van den Audenaerde, 1969) in the Rokel/Seli River, West Africa
}

\section{Komba Jossie Konoyima ${ }^{1, a^{*}}$, Amidu Mansaray ${ }^{2, b}$, Ernest Tom Ndomahina ${ }^{3, c}$ and Elizabeth Boima Amara ${ }^{3, \mathrm{~d}}$}

${ }^{1}$ Institute of Marine Biology and Oceanography, University of Sierra Leone, Freetown, Sierra Leone

${ }^{2}$ Department of Aquaculture and Fisheries Management, Njala University, Njala Campus, Sierra Leone

${ }^{3}$ Institute of Marine Biology and Oceanography, University of Sierra Leone, Freetown, Sierra Leone

a*konoyimak@gmail.com*, bmansarayahmid@gmail.com, cernest_ndomahina@yahoo.com, deboima2002@gmail.com

Keywords: Allometric growth, Isometric growth, wellbeing, environment, spawning, ecosystem

\begin{abstract}
This study was conducted in the lower, middle and upper reaches of the Rokel/Seli River, Northern Sierra Leone. There is a research gap on the growth or wellbeing of tilapia fish species in Sierra Leone. The objective of this study is to determine the length-weight relationship and condition factor of Coelotilapia joka from the main river channel. This research could contribute to promoting an agenda for fish culture practices for the fish. A total of 228 specimens of Coelotilapia joka were collected using gill nets. Fish length and weight measurements were done using fish measuring board and digital weighing balance respectively. Measurement for water quality was made using the Jemway multi-parameter water quality measuring device (Model: J970, Barloworld Scientific, United Kingdom). The values for regression coefficient "b" gave 2.5437, 2.1841 and 2.4585 for males, females and combined sex respectively, implying a negative allometric growth in the fish at $(b<3.0)$. Similarly, a strong positive linear correlation " $r$ " exists for male $(0.947)$ and female (0.827) species of $C$. joka. Mean condition coefficient $(\mathrm{K})$ was $2.113 \pm 0.309$ for males and $1.969 \pm 0.359$ for females. The lowest condition factor for male, 1.995 and female, 1.743 were recorded in March and April respectively, and the highest, 2.552 and 2.067 recorded in August. These values, however, suggest that the fish was in good condition $(K>1)$. The difference in " $K$ " for both sex is significant $(\mathrm{p}<0.05)$. A study for a period of one year could, however, provide a complete analysis of seasonal variations in growth and condition of the fish.
\end{abstract}

\section{Introduction}

The Rokel/Seli River is the third largest of nine (9) major river systems in Sierra Leone, with a total length of $380 \mathrm{~km}$ and a drainage area $10,620 \mathrm{~km}^{2}$ [1]. Numerous anthropogenic activities including intensive subsistence and commercial fishing activities are taking place in and around the river by local residents.

Fish is an extremely important source of protein in the diets of many people [2], and the tilapia fishes are amongst the important groups of fresh water fish species particularly in rural areas of Sierra Leone. In addition, fish plays an important role in the development of a nation [3, 4]. Studies have shown that the aquatic ecosystem which is home for fish is often contaminated by anthropogenic activities including sewerage [5], pesticides [6, 7] and effluents from oil palm processing [8,9]. Environmental degradation has its impact on the organism found in such environment [10]. It could reduce growth rates and causes a decrease in the average age of the fish [11]. Such anthropogenic influence on the aquatic environment emphasizes the importance of a study on the status of fish in a given ecosystem. Knowledge of length-weight and condition factor $(\mathrm{K})$ is vital in the study of fish biology [12]. Length-weight relationship of a fish is an essential tool for fishery management and conservation $[3,13,14,15]$. This is because a change in length and weight tell about the age of the fish [10]. The data can also be used in estimating the mortality rate and assess the sustainability of the fishery stock [11]. Length-weight relationships can be used to 
predict weight from length measurements made in the yield assessment [16]. Isometric growth, negative or positive allometric growth is used to describe body shape in fish [17].

The condition factor $(\mathrm{K})$ provides vital insight of the physiological state of the fish in relation to its habitat $[3,18]$. It shows the level of well-being of a fish and is a useful index for monitoring of feeding intensity, age, and growth rates in fish [19]. Condition factor also contributes to efficient management of a fishery as it provides vital information on the life cycle of fish species [20]. In addition, condition factor is reflective of the interactions between biotic and abiotic factors in the physiological condition of fishes [13]. Higher value in condition factor indicates that the fish has attained a favorable condition [12]. In tilapia, the size composition can be greatly affected by the physical and biological composition of their environment [21]. Moreover, the tilapia fishes are amongst the commonly exploited [22] and edible groups of fresh water fish species in Sierra Leone. This group of fish could contribute to local economy through fish farming practices if well managed in Sierra Leone. Unfortunately, there is a research gap in the study of the growth and conditions of tilapia species in the Sierra Leone waters. Of all species in this group which occur in Sierra Leone, a study on the allometric growth has been conducted for only Coptodon louka [1]. Most studies have been on the ecology, distribution and diversity of freshwater fish species in Sierra Leone [22]. The objective of the current study is to investigate the growth and wellbeing of Coelotilapia joka in the Rokel/Seli River. This research could contribute to promoting an agenda for fish culture practices for the fish, which in turn could help reduce the current fishing pressures on marine capture fisheries in Sierra Leone as a management measure.

\section{Theory}

Good knowledge about the ichthyofaunal characteristics of a river basin is a first step to evaluating the quality and disturbance of aquatic habitats [23, 24]. Knowledge of length-weight and condition factor $(\mathrm{K})$ is vital in the study of fish biology [12]. Length-weight relationship of a fish is an essential tool for fishery management and conservation [3, 13-15]. This is because a change in length and weight tells about the age of the fish [10], and the data can be used to estimate the mortality rate, and assess the yield of fish stock [11]. Length-weight relationship of fishes can be used in estimating average weight of the fish of a given length group by establishing a mathematical relation between the two $[25,26]$. In fisheries science, the condition factor is required to determine any possible differences between unit stocks of the same species in terms of growth or wellbeing [27], based on the hypothesis that heavier fish of a particular length are in a better physiological condition $[28,29]$. [18] had suggested that there may be differences in the condition factor due to environmental conditions such as pollution. In addition, the aquatic ecosystem is constantly been influenced by anthropogenic activities through the introduction of sewage [5], pesticides [6,7] and agricultural runoffs $[8,9]$. These activities have their impacts on the organisms found in such environment [10]. Impacts may include reduced growth rates and a decrease in the average age of the fish [11]. Very little studies have been conducted on the growth and conditions of tilapia species in Sierra Leone. Several studies had focused on the ecology, distribution and diversity of fish species $[22,30]$. It is on these bases that this study is undertaken.

\section{Materials and Methods}

\section{Site locations}

The study was conducted in the lower reach, middle reach and upper reach of the Rokel/Seli River. The river is called Seli or Rokel in its upper and lower reaches respectively, and has been identified as one of a series of narrow, more or less parallel river basins draining the Guinea highlands into the Atlantic, none of which, in African terms, are long [22]. The Seli rises in the North-Northeast of the country, near the border with Guinea, and flows South-West across the Interior Plateau for around $100 \mathrm{~km}$ South-East of Fadugu, where the river transects the Sula Mountains and flows out of the plateau across Bumbuna Falls, and then drops around 40m into the Interior Lowlands [22]. The river is then known as the Rokel, and meanders $350 \mathrm{~km}$ across the 
gently sloping interior lowlands, down to the sea, east of Freetown [1,22]. One particular feature of the river is the Bumbuna falls, a cascade of around 30m high, just above which is the site for the Bumbuna Hydroelectric Project [22]. The Bumbuna dam site is located on the upper reaches of the Rokel/Seli River in the valleys of the Sula Mountains about $200 \mathrm{~km}$ North-East of the capital city, Freetown. The region where the river occurs has been termed by various authors as 'AtlanticoGuinean' [31, 32], Guinean [33] or Upper Guinean [34, 35].

The climate in the North is in conformity with climatic conditions of Sierra Leone, a tropical climate with distinct dry season (November to April) and wet season (May to October) [36]. In Bumbuna, the wet season begins in May and ends in October, and is characterised by heavy rainfall (reaching a maximum of around 600mm in August). Rainfall decreases as the dry season progresses until in February there is virtually no rain at all [22]. Fig.1 illustrates the various sampling positions in the Rokel/Seli River, northern Sierra Leone.

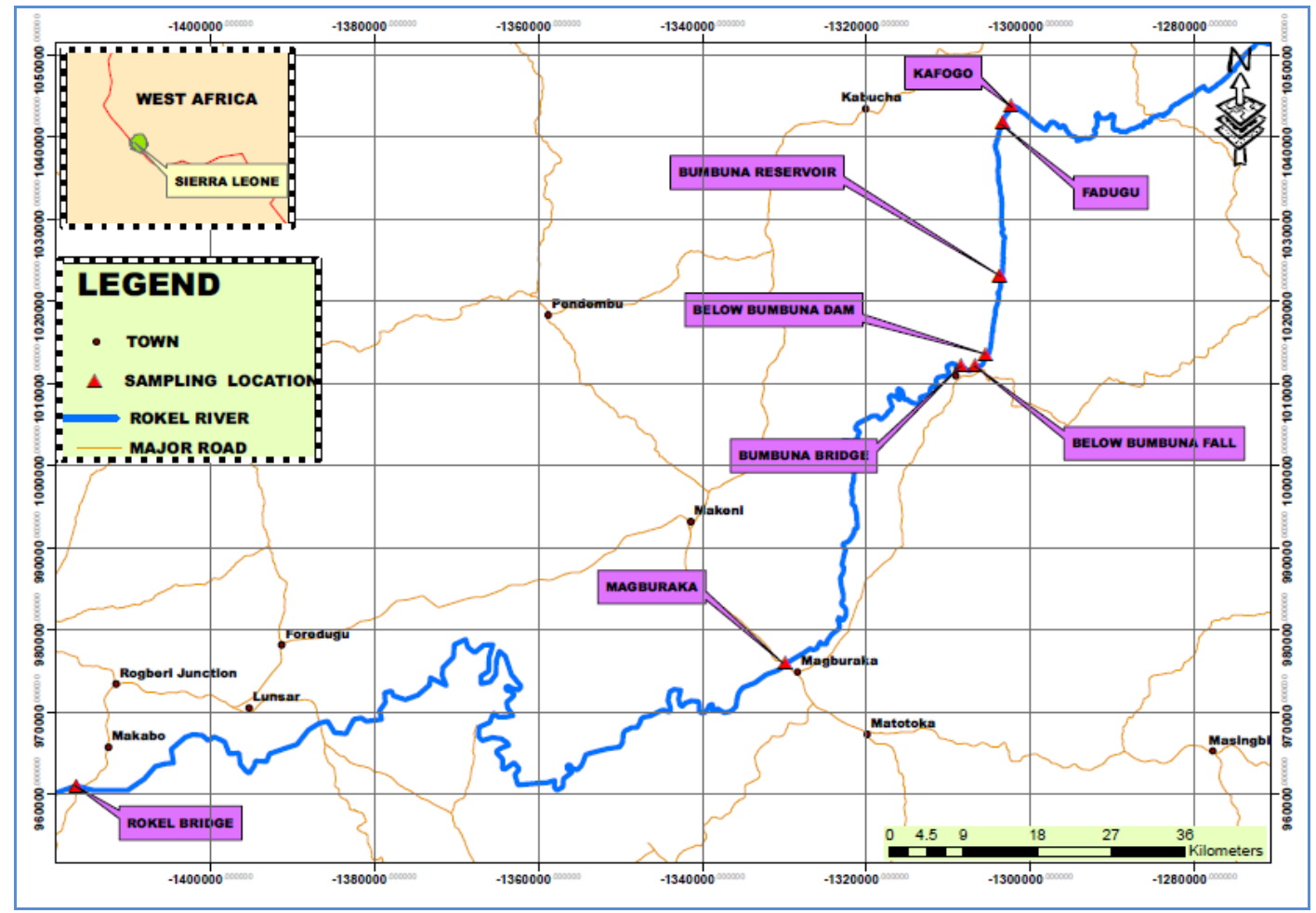

Figure 1. Map illustrating study locations

As shown in Fig. 1, eight sites were selected for this study in three regions of the Rokel/Seli River and include the upper reach (Fadugu and Kafogo), middle reach (Bumbuna Dam Area) and lower parts (Rokel Bridge and Manepeh/Magburaka) of the main river basin. These sites were selected in connection to previous study on fish species assemblage of the Rokel/Seli River [22]. Table 1 gives the GPS coordinates of the study locations in the river.

Table 1. Study locations at three main regions of the Rokel/Seli River

\begin{tabular}{|c|c|c|c|c|}
\hline Description & Region & Latitude & Longitude & $\begin{array}{c}\text { Altitude } \\
(\mathbf{m})\end{array}$ \\
\hline Rokel Bridge & Lower Reach & $08^{\circ} 35.888^{\prime}$ & $12^{\circ} 43.287^{\prime}$ & 08.4 \\
\hline Magburaka & Lower Reach & $08^{\circ} 44.001^{\prime}$ & $11^{\circ} 56.696^{\prime}$ & 84.7 \\
\hline Bumbuna bridge & Middle Reach & $09^{\circ} 03.127^{\prime}$ & $11^{\circ} 45.194^{\prime}$ & 125.4 \\
\hline Below Bumbuna Falls & Middle Reach & $09^{\circ} 03.222^{\prime}$ & $11^{\circ} 44.254^{\prime}$ & 139.2. \\
\hline Below Bumbuna Dam & Middle Reach & $09^{\circ} 03.971^{\prime}$ & $11^{\circ} 43.517^{\prime}$ & 165.3 \\
\hline Bumbuna Reservoir & Middle Reach & $09^{\circ} 08.969^{\prime}$ & $11^{\circ} 42.616^{\prime}$ & 181.4 \\
\hline Fadugu & Upper Reach & $09^{\circ} 19.5880^{\prime}$ & $11^{\circ} 42.7816^{\prime}$ & 298.3 \\
\hline Kafogo & Upper Reach & $09^{\circ} 20.0712^{\prime}$ & $11^{\circ} 42.4379^{\prime}$ & 299.8 \\
\hline
\end{tabular}




\section{Sample size and collection of fish samples}

A total of 228 specimens of $C$. joka were obtained from the Rokel/Seli River in two seasons. Eight months were planned for sampling, January to August, 2012. January-April is in the dry season, and May-August in the wet season. Each study phase in a month was designed to last for a period of 14 days. Fish samples were obtained using $80 \mathrm{~m}$ long light-weight gill nets with $4 \mathrm{~cm}$ and $8 \mathrm{~cm}$ mesh sizes set either across the river or in parallel to the water current under faster flows to avoid being swept away. The gill nets were set in the morning and catches retrieved in the late afternoon. At night, the nets were laid alongside river banks to capture more nocturnal fish [22]. Fresh fish samples were also purchased from local commercial fishers. Specimens were placed in plastic containers for further analysis.

\section{Fish identification}

Collected fish samples were placed in plastic containers and taken to a temporary laboratory in the field for identification with the aid of standard keys and referenced texts [37,38]. The colour of $C$. joka in life form on ground is dark brown to blackish, yellowish cross bars (up to 8) on it sides and head running from just behind the eye to the caudal peduncle. Head is dark brown, with a lighter or yellowish narrow band between eyes and a horizontal band on snout. Pectoral fins yellowish to transparent; pelvic fins brownish-black, lighter anteriorly, especially in juveniles; Caudal fin, dorsal and anal fins brownish-black.

\section{Sex determination}

Sexing of the fish was done by observing the genital papilla on the underside of the fish, to the rear of the anus and before the anal fin. Males have one urogenital opening while females have separate openings for urine and for eggs as described in [39].

\section{Measurements of total length (TL) and weight}

Weight measurement of specimens of Coelotilapia joka collected from sampling was done using digital weighing balance (Model: CS2000; Ohaus corporation, China) to the nearest $0.1 \mathrm{~g}$ while measurement of total length involved spanning from the snout to the tip of the caudal fin using standard fish measuring board to the nearest $0.1 \mathrm{~cm}$ as described in [40]. In order to ensure accuracy in weight measurement, fish specimens were placed on filter paper to remove excess water before weighing [41].

The length-length relationship was analysed by the relation

$$
\mathrm{W}=\mathrm{aL}^{\mathrm{b}}[19,42]
$$

where $\mathrm{W}=$ Total weight of fish $(\mathrm{g}), \mathrm{L}=$ Total Length of fish $(\mathrm{cm}), \mathrm{a}=$ intercept, and describes the rate of change of weight with length, $b=$ slope, the weight at unit length. In addition, the parameters "a" and "b" in the formula were estimated through logarithmic transformation of the total length (TL) and total weight (W) of the fish in the form, $\log W=b \log L+\log a$, and Loga $=$ intercept on the y-axis [43]. The degree of association between the length and weight $\left(\mathrm{R}^{2}\right)$ was computed from the linear regression analysis.

\section{Condition factor}

Values of the condition factor for male and female species of Coelotilapia joka were obtained through the formula [44]

$$
\mathrm{K}=100 \mathrm{~W} / \mathrm{L}^{\mathrm{b}} \text {, }
$$

where $\mathrm{K}=$ condition factor, $\mathrm{W}=$ whole body weight of the fish $(\mathrm{g}), \mathrm{L}=$ the total length of the fish (cm).

The advantage in using this relation is that the value " $b$ " is not constant. " $b$ " is the growth exponent obtained from the length-weight relation and varies by species [45]. This relation is also seen to be very useful in modern day's studies [39, 46, 47]. 


\section{Water sampling}

For this study, selected water quality parameters including surface water temperature, $\mathrm{pH}$, dissolved oxygen concentration (DO) and conductivity were measured in-situ using the portable Jemway multi-parameter water quality measuring device (Model: J970; Barloworld Scientific, United Kingdom). Water samples were collected from the Lower, Middle and Upper Reaches of the Rokel/Seli River.

\section{Data analysis}

A linear transformation of length and weight of $C$. joka was completed using natural logarithm at the observed lengths and weights. The LWR regression equation was used to calculate the regression coefficient " $b$ " (slope of regression line of weight and length) and the coefficient of determination $\left(\mathrm{R}^{2}\right)$. The correlation coefficient (r) that is the degree of association between the length and weight was also computed by the relation, $r=$ sqrt $\left(\mathrm{R}^{2}\right)$. These analyses were performed for the male, female and combined sexes of the fish. Statistical analysis using the Student's t-test for significant difference in male and female condition factors of the fish was completed using the Microsoft Excel (ver., 2010) computer analysis package. A Chi-square test statistic (ANOVA) was used to test for significance in the sex ratio of the fish and of selected water quality parameters among different regions of the Rokel/ Seli River. Similarly, descriptive statistics were employed in calculating the means and standard errors of values of condition factor, regression coefficient and water quality parameters.

\section{Results}

\section{Length-Weight Relationship}

A total of 228 individuals of $C$. joka were collected for this study. The values of the regression coefficient " $b$ " obtained from the LWR for 30 male and 198 female species of the fish using the best-fit regression of total weight (TW) on total length (TL) by logarithmic transformation gave $2.5437,2.1841$ and 2.4585 for the males, females and combined sexes respectively. Fig. 2 (a-c) explain a) Length-Weight Relationship for male; b) Length-Weight Relationship for female; c) Length-Weight Relationship for combined sex.

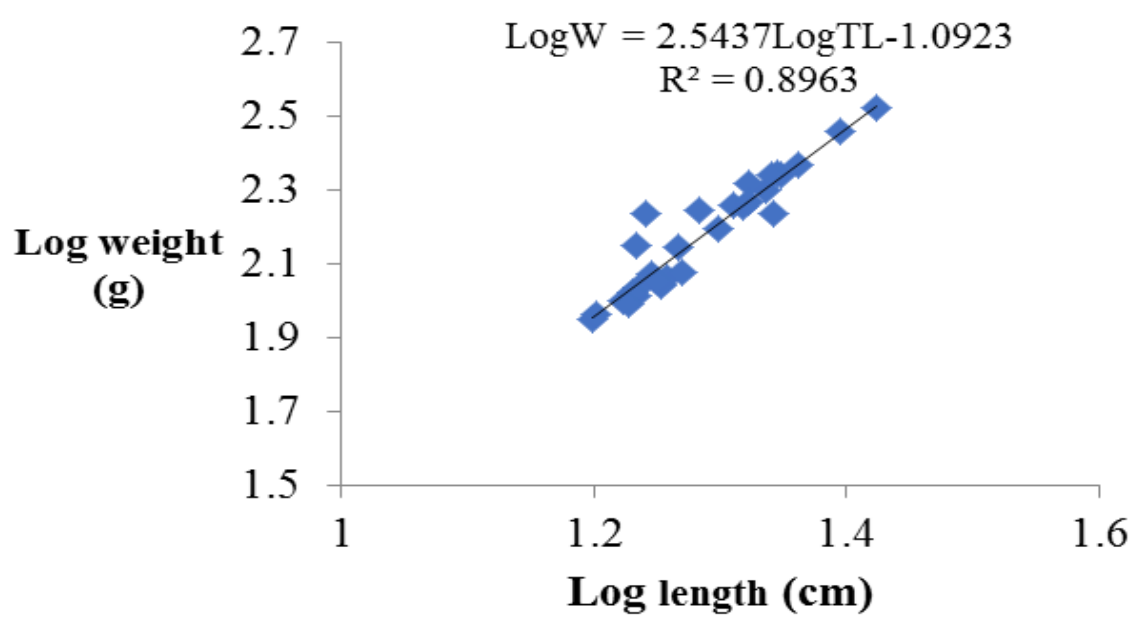

Figure 2a. Logistic Length-Weight Relationship for male C. Joka 


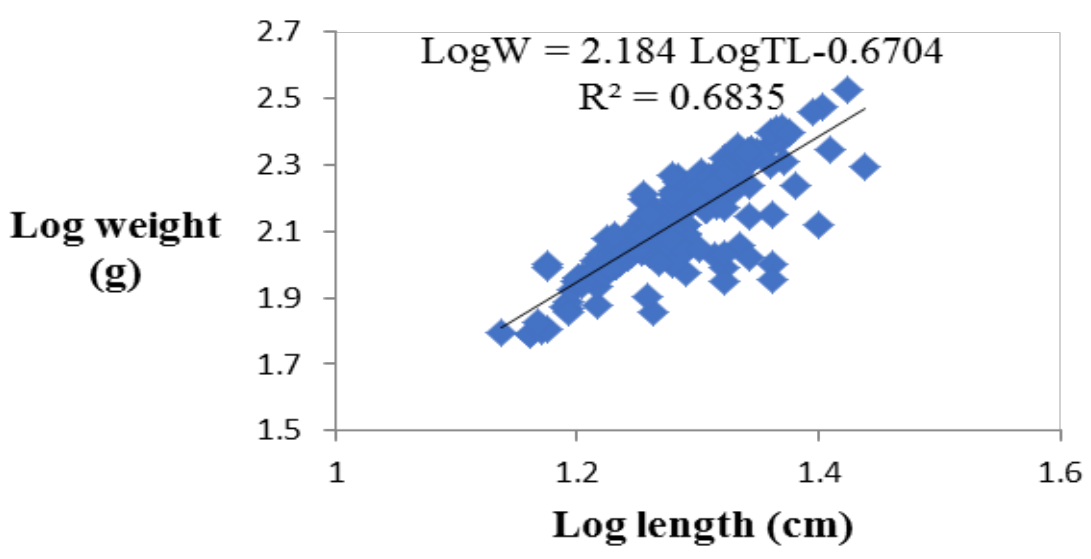

Figure 2b. Logistic Length-Weight Relationship for female C. Joka

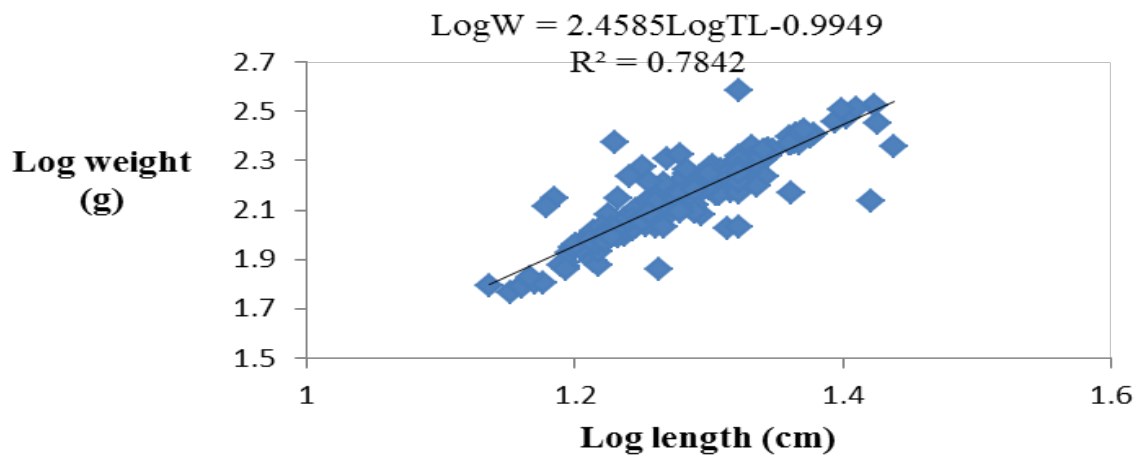

Figure 2c. Logistic Length-Weight Relationship for combined sex of C. Joka

The best-fit regression line showed a strong coefficient of determination $\left(\mathrm{R}^{2}\right)$ between length and weight for the combined sex of $C$. joka (0.784). However, the high " $\mathrm{R}^{2}$ " value for the males (0.896) compared to females (0.684) shows that the regression line for the males is closest to bestfit. The mean length and mean weight, regression coefficient, correlation factor ( $r$ ), coefficient of determination $\left(\mathrm{R}^{2}\right)$ and condition factor $(\mathrm{K})$ of $C$. joka are given in Table 2.

Table 2. Mean length $( \pm \mathrm{SE})$, mean weight $( \pm \mathrm{SE})$, regression coefficients $(b)$, coefficient of determination $\left(\mathrm{R}^{2}\right)$, correlation factor $(\mathrm{r})$ and condition factor $(\mathrm{K})$ for male, female and combined sex of C. joka

\begin{tabular}{|c|c|c|c|c|c|c|c|c|c|}
\hline Sex & $\mathbf{n}$ & $\begin{array}{c}\text { Mean } \\
\text { Length } \\
{[\mathbf{c m}]}\end{array}$ & $\begin{array}{c}\text { Mean } \\
\text { Weight } \\
{[\mathrm{g}]}\end{array}$ & $\mathbf{a}$ & $\mathbf{b}$ & $\mathbf{R}^{2}$ & $\mathbf{r}$ & \multicolumn{2}{|c|}{$\begin{array}{c}\text { Condition factor } \\
{[\mathrm{K}]}\end{array}$} \\
\hline Male & 30 & $19.47 \pm 2.70$ & $160.60 \pm 61.31$ & 1.09 & 2.54 & 0.896 & 0.947 & $\begin{array}{c}1.619- \\
3.272\end{array}$ & $2.113 \pm 0.309$ \\
\hline Female & 198 & $19.20 \pm 2.49$ & $141.05 \pm 48.77$ & 0.67 & 2.18 & 0.684 & 0.827 & $\begin{array}{c}0.734- \\
2.163\end{array}$ & $1.969 \pm 0.359$ \\
\hline Combined & 228 & $19.32 \pm 2.51$ & $153.32 \pm 55.27$ & 0.99 & 2.46 & 0.784 & 0.885 & $\begin{array}{c}0.745- \\
2.794\end{array}$ & $2.070 \pm 0.429$ \\
\hline
\end{tabular}

$*\left(\mathrm{r}=\right.$ regression correlation; $\mathrm{R}^{2}=$ coefficient of determination; $\mathrm{n}=$ number of samples; $\mathrm{b}=$ slope/regression coefficient from the LWR; $\mathrm{a}=$ intercept from the LWR) 
Similarly, a strong linear correlation " $r$ " was obtained in this study for the males (0.947), females (0.827) and combined sex (0.885) of the fish.

\section{Condition factor}

The condition factor $(\mathrm{K})$ of $C$. joka showed the range of 1.619-3.272, 0.734-2.163 and 0.745-2.794 with mean values of $2.113 \pm 0.309,1.969 \pm 0.359$ and $2.070 \pm 0.429$ for male, female and combined sex respectively (Table 2). The lowest condition factor for male, 1.995 was recorded in April, and the highest, 2.552 in August. For female, the lowest value, 1.743 was recorded in March and the highest value, 2.067 in August. For combined sex, the lowest value, 0.500 was recorded in January and the highest, 2.184 in August. Fig. 3 (a-c) provide the monthly mean condition factors $(\mathrm{K})$ for male, female and combined sex of $C$. joka. Fig. 3c further shows standard bars on the chart that indicate how accurately the mean value of condition factor represents the data, and it is shown that both upper and lower bars are small.

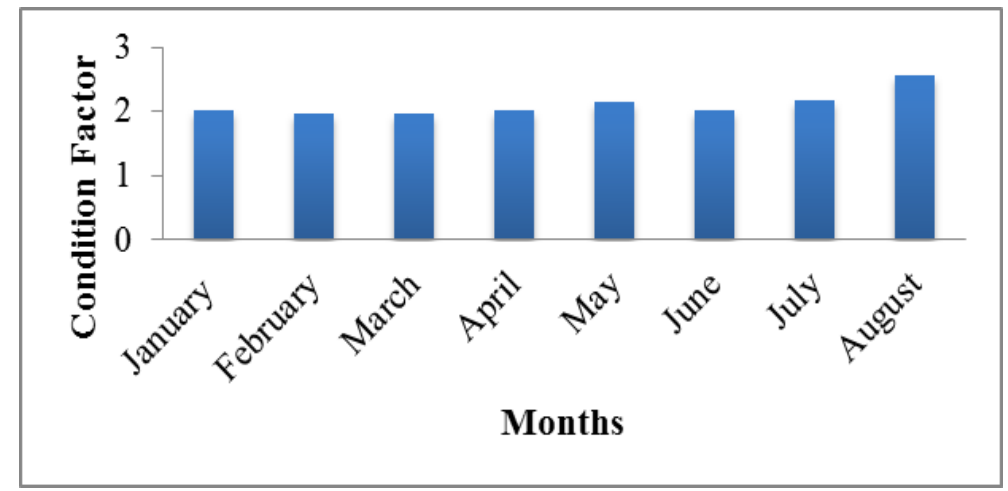

Figure 3a. Monthly mean values of condition factor for male $C$ joka

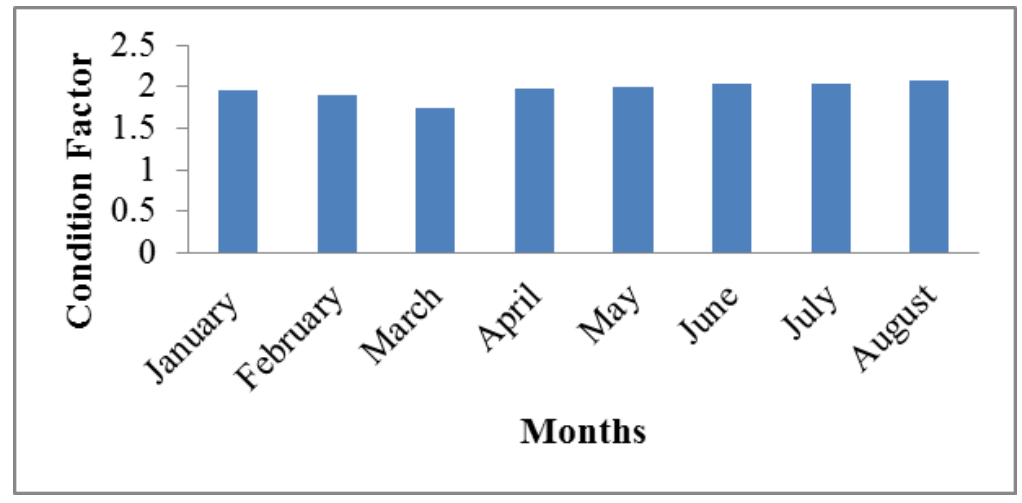

Figure 3b. Monthly mean values of condition factor for female $C$ joka

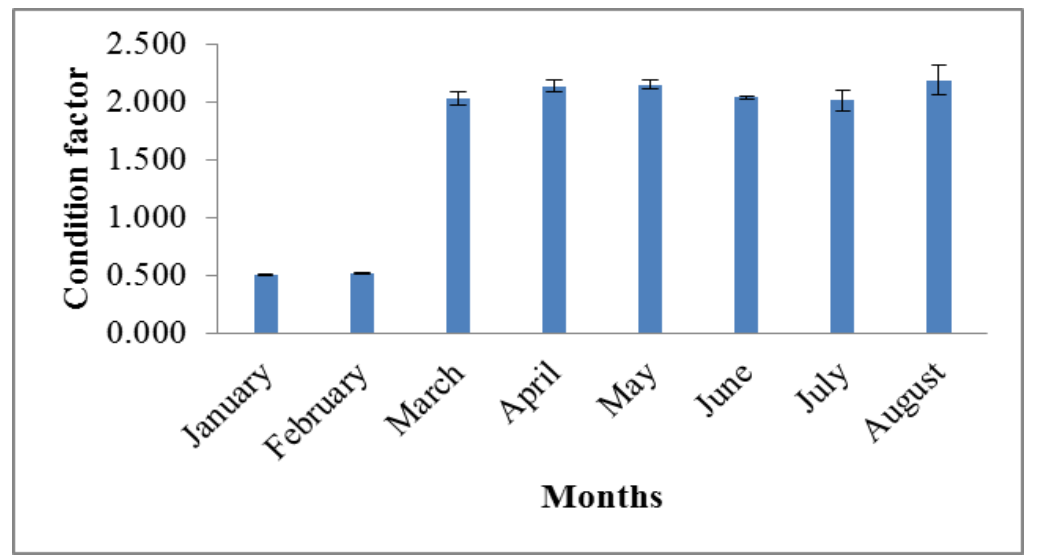

Figure 3c. Monthly mean values of condition factor for combined sex of $C$ joka (with standard error bars) 
From a Student's t-test (t), there was a significant difference in condition factor (df. 42; $\alpha=0.05$; Probability $=0.025 ; \mathrm{t}=2.3$, two=tailed) for the male and female species of the fish at $(\mathrm{P}<0.05)$. The mean values of condition factor for $C$. jok $a$ are given in Table 2.

\section{Water quality analyses}

The $\mathrm{pH}$ of the river ranges from 5.4 to 7.1 , with mean values of $6.98 \pm 0.96,6.25 \pm 0.52$ and $6.24 \pm 0.60$ for the upper, middle and lower reaches respectively. Similarly, DO concentration ranged from $1.1 \mathrm{mg} / 1-12.9 \mathrm{mg} / \mathrm{l}$ with mean values of $4.57 \pm 3.34,6.85 \pm 2.71$ and $7.02 \pm 2.68$ in the upper, middle and lower reaches of the river. In addition, values for water temperature ranged from $23.5^{\circ} \mathrm{C}$ to $29.5^{\circ} \mathrm{C}$ with mean temperature of $26.73 \pm 1.35,25.58 \pm 0.91$ and $25.85 \pm 1.60$ for the upper, middle and lower reaches of the river. Conductivity values range from $20.0 \mu \mathrm{Scm}^{-1}$ to $63.0 \mu \mathrm{Scm}^{-1}$ with mean of $38.24 \pm 12.52,43.39 \pm 10.64$ and $32.18 \pm 11.14$ for the upper, middle and lower reaches of the Rokel/Seli River respectively. However, a Chi-square $\left(\chi^{2}\right)$ analysis for this study (ANOVA, df. 2, $\alpha=0.05$, one-tailed) showed no significant difference in the water quality parameters for the three regions (Upper, Middle and Lower reaches) of the river. The mean values (with standard errors) for the water quality parameters are given in Table 3.

Table 3. Mean values ( \pm SE) of water quality parameters in the Rokel/Seli River

\begin{tabular}{|c|c|c|c|c|}
\hline \multirow{2}{*}{$\begin{array}{c}\text { Sampling } \\
\text { areas }\end{array}$} & \multicolumn{4}{|c|}{ Parameter } \\
\cline { 2 - 5 } & Temperature $\left[{ }^{\mathbf{0}} \mathbf{C}\right]$ & DO [mg/l] & $\mathbf{p H}$ & Conductivity $\left[\boldsymbol{\mu S c m}^{-1}\right]$ \\
\hline Upper Reach & $26.73 \pm 1.35$ & $4.57 \pm 3.34$ & $6.98 \pm 0.96$ & $38.24 \pm 12.52$ \\
\hline Middle Reach & $25.58 \pm 0.91$ & $6.85 \pm 2.71$ & $6.25 \pm 0.52$ & $43.39 \pm 10.64$ \\
\hline Lower Reach & $25.85 \pm 1.60$ & $7.02 \pm 2.68$ & $6.24 \pm 0.60$ & $32.18 \pm 11.14$ \\
\hline
\end{tabular}

\section{Sex Ratio}

The Chi-square $\left(\chi^{2}\right)$ test conducted for this study shows a significant difference in sex for the fish. As given in Table 4, the calculated $\chi^{2}$ value gave 123.8. This is higher than the tabulated value of 3.84 for $1 \mathrm{df}$. at $5 \%$ level of significance.

Table 4. Chi-square $\left(\chi^{2}\right)$ test on sex ratio of $C$. joka

\begin{tabular}{|c|c|c|c|c|c|c|c|c|}
\hline Sex & $\begin{array}{c}\text { Observed } \\
\text { number } \\
{[\mathrm{O}]}\end{array}$ & $\begin{array}{c}\text { Expected } \\
\text { number } \\
{[E]}\end{array}$ & O-E & $\begin{array}{l}(\mathrm{O}- \\
\mathrm{E})^{2}\end{array}$ & $\begin{array}{c}(\mathrm{O}- \\
\mathrm{E})^{2} / \mathrm{E}\end{array}$ & $\begin{array}{l}\sum(\mathbf{O}- \\
\mathbf{E})^{2} / \mathbf{E}\end{array}$ & $\begin{array}{c}\text { Calculated } \\
\mathbf{X}^{2}\end{array}$ & $\begin{array}{c}\text { Tabulated } \\
\mathbf{X}^{2}\end{array}$ \\
\hline Male & 30 & 114 & -84 & 7056 & 61.89 & \multirow{2}{*}{123.78} & \multirow{2}{*}{123.78} & \multirow{2}{*}{3.84} \\
\hline Female & 198 & 114 & 84 & 7056 & 61.89 & & & \\
\hline $\begin{array}{c}\text { Sex } \\
\text { Ratio } \\
(\mathrm{M}: \mathrm{F})\end{array}$ & $1: 7$ & $1: 1$ & & & & & & \\
\hline
\end{tabular}

Table 5 further provides monthly catch records for male and female fish of $C$. joka. Female species dominated the catch in all phases of the survey. Catches were high in periods of the wet season (May-August) than in the dry season (January-April).

Table 5. Monthly catch records for male and female species of C. joka

\begin{tabular}{|c|c|c|c|c|c|c|c|c|c|}
\hline Species & January & February & March & April & May & June & July & August & Total \\
\hline Male & 2 & 5 & 2 & 7 & 3 & 1 & 6 & 4 & 30 \\
\hline Female & 22 & 10 & 12 & 24 & 25 & 12 & 52 & 41 & 198 \\
\hline Combined sex & 24 & 15 & 14 & 31 & 28 & 13 & 58 & 45 & 228 \\
\hline
\end{tabular}




\section{Discussion}

The length-weight relationship (LWR) is key to providing useful information on growth patterns in fish [18]. Fish generally passes through different stages of development which can be defined by different LWR. For this study, in spite of the slight increase in length and weight of male over female species of the fish, both sexes of $C$. joka were in the light group of fishes with value of $b<3.0$, implying a negative allometric growth in the fish. It also implies that the growth in size of the fish is not proportionate to the increase in weight [48]. This suggests inadequate feeding level and diets composition in the fish with the potential to affect nutritional conditions that favour growth in weight. Restrictions in mobility due to increased water current in the peak of the wet season (July-August) and by large hydro-electric power dam in the upper reach of the river may further limit food preferences of the fish in the area. Fishing pressure as well as changes in environmental quality could have exacerbated the problem. Recorded values for $\mathrm{pH}$ and dissolved oxygen (DO) concentrations in the river were above acceptable limit with the potential to affect immunological response in the fish that could consequently retard growth in weight. $\mathrm{pH}$ values within optimum $(7-10)$ and higher DO levels $(<5)$ have been seen to favour fish growth [49-53]. Similar $\mathrm{pH}$ range had been shown to support the best weight gain in oreochromis niloticus [54]. Other studies have shown that environmental degradation has impact on the organisms found in such environment [10]. It could reduce growth rates and cause a decrease in the average age of the fish [11]. However, the "b" values obtained for this study were within recommended range of 2-4 [55-57] as ideal for fresh water fishes. Comparatively, a negative allometric growth with "b" value of 2.91 had also been reported for Tilapia zillii in fresh water [58]. In addition, the "b" value obtained for combined sex for this study was within the value obtained for another cichlid fish [1].

In the study of fish, the condition factor $(\mathrm{K})$ is used in comparing its condition, size or wellbeing [59]. Condition factor is also important in the monitoring of feeding intensity, age and growth rates in fish [60]. Related study had shown that the condition factor is strongly influenced by both biotic and abiotic environmental conditions, and can be used to assess the ecological habitat of fish species [61]. This study provides mean condition coefficient $(\mathrm{K})$ of $2.113 \pm 0.309$ for male and $1.969 \pm 0.359$ for female species of $C$. joka. These values are greater than one, indicating that the fish was healthy and in good condition. "K" value greater than one $(>1)$ had been recorded for another tilapia species, Oreochromis niloticus [18], suggesting that the fish was above average in terms of condition. [62] inferred that value of condition factor higher than one suggests good health in fish. However, other researchers have hypothesized that heavier fish of a particular length are in a better physiological condition than the lighter ones $[28,29]$. The values for this study showed differences in condition factor for male and female species of $C$. joka and significant $(\mathrm{P}<0.05)$. Such difference in condition factor with higher values for the males could be attributed to different mode of responses to changes in environmental conditions [11, 21]. Moreover, small error bars obtained in the bar-chart for the monthly mean condition factor for combined sex C. joka implies a low spread of the data around the mean, which further suggests that the data are more reliable. Further, high "K" values were recorded in August, the peak of the wet season. This period could be most favourable for the fish since at these times there is less fishing pressure by commercial fishers and probably low residence time of contaminants in the river, compared to periods of the dry season (January-March). It is possible that such favourable and stress-free environmental condition for the fish is maintained for the rest of the wet periods (September-November). [63] inferred that variation in condition factor of a fish could be associated to differences in fishing and industrial activities in a river. [46] further concurs that condition factors in fish are associated with comfortability of the fish in a system. Variations in condition factor are influenced by many biotic and abiotic factors such as phytoplankton abundance, predation, water temperature and dissolve oxygen concentrations among others which may not favour the growth and survival of all the species in the ecosystem [46].

The study also provided a significant difference in sex for $C$. joka with female to male sex ratio, 1:7. [64] had recorded larger number of females for another tilapia species, Sarotherodon galilaeus, with 3 males and 5 females of eight individual specimens of the fish. For this study, it is possible that during sampling, an extremely higher catch was made in a spawning period, probably 
in July-August, the peak of the wet season. As typical of tilapia species, males build and clean spawning nests in their territory during spawning seasons [65]. It could be that the females which enter and leave the nests probably in schools, are ultimately left much vulnerable to catch or predation during such periods.

\section{Conclusions}

The study investigated the length-weight relationship, condition factor and sex ratio of Coelotilapia joka, a type of cichlid fish from the Rokel/Seli River, Sierra Leone. There were 228 individual specimens of $C$. joka with a male to female sex ratio, 1:7. Both sexes of the fish showed negative allometric growth pattern $(b<3.0)$. Values of $\mathrm{pH}$ and $\mathrm{DO}$ however showed range not favourable for growth of fish which may have possibly affected the growth in weight of the fish. However, values of the condition factor for this study showed that the fish was healthy and in good condition for consumption. In addition, better conditions in the fish were attained in periods of the wet season (July-August). A study over one year period, however, is eminent to providing a complete analysis of seasonal variations in length-weight relationship and condition factor for $C$. joka and other tilapia species.

\section{Conflict of Interest}

The publication is self-sponsored and the authors declare that there is no conflict of interest.

\section{Acknowledgements}

The authors are grateful to the supporting staff of the Institute of Marine Biology and Oceanography, University of Sierra Leone, and also to the Bumbuna Watershed Management Project for providing funds and enabling environment for the study.

\section{References}

[1] A.I. Payne, R.C. Wakeford, E.T. Ndomahina, Bumbuna Hydroelectric Project Baseline Biodiversity Surveys. Final Draft Baseline Fish Survey. Nippon Koel U.K, 2006.

[2] T.S. Imam et al., Length-weight relationship and condition factor of four fish species from Wasai Reservoir in Kano, Nigeria. African Studies. 6 (2010) 125-130.

[3] C. I. Atama et al., Length-Weight Relationship and Condition Factor of Six Cichlid (Cichilidae: Perciformis) Species of Anambra River, Nigeria. Journal of Fisheries and Aquaculture. 4(2) (2013) 82-86.

[4] W. Ndiaye et al., The length-weight relationship and condition factor of white grouper (Epinephelus aeneus, Geoffroy Saint Hilaire, 1817) at the south-west coast of Senegal, West Africa. International Journal of Advanced Research. 3(3) (2015) 145-153.

[5] S.C. Izah, T.C.N. Angaye, Environmental Impacts of Oil palm processing in Nigeria. Biotechnological Research. 2(3) (2016) 132-141.

[6] I.R. Inyang, N.C. Okon, S.C. Izah, Effect of glyphosate on some enzymes and electrolytes in Heterobranchus bidosalis (a common African catfish). Biotechnological Research. 2(4) (2016).161-165.

[7] I.R. Inyang, K. Akio, S.C. Izah, Effect of dimethoate on lactate dehydrogenase, creatinine kinase and amylase in Clarias lazera. Biotechnological Research. 2(4) (2016). pp155- 160.

[8] S.C. Izah, T.C.N. Angaye, E.I. Ohimain, Environmental Impacts of Oil palm processing in Nigeria. Biotechnological Research. 2(3) (2016) 132-141. 
[9] M. Chandel, S.K. Tank, Cytogenetic Study of Allium cepa Root Tip Cells treated with Textile Effluent. Biotechnological Research. 2(3) (2016) 100-103.

[10] E.I. Seiyaboh, G.A. Harry, S.C. Izah, Length-Weight Relationship and Condition Factor of Five Fish Species from River Brass, Niger Delta. Biotechnological Research. 2(4) (2016) 187-192.

[11] A. Samat et al., Length-weight Relationship and Condition Factor of Pterygoplichthys pardalis (Pisces: Loricariidae) in Malaysia Peninsula. Research Journal of Fisheries and Hydrobiology. 3(2) (2008) 48-53.

[12] A. Nehemia, J.D. Maganira, C. Rumisha, Length-Weight relationship and condition factor of tilapia species grown in marine and fresh water ponds. Agriculture and Biology Journal of North America. 3(3) (2012) 117-124.

[13] P.L. Lalrinsanga et al., Length Weight Relationship and Condition Factor of Giant Freshwater Prawn Macrobrachium rosenbergii (De Man, 1879) Based on Developmental Stages, Culture Stages and Sex. urkish Journal of Fisheries and Aquatic Sciences. 12(4) (2012) 917-924.

[14] K. Mahmood et al., Length-weight relationship and condition factor of Ilesha melastoma (Clupeiformes pristigasteridae) off Pakistan. Pakistan Journal of Zoology. 44(1) (2012). 71 77.

[15] A. I. Hart, J. F. N. Abowei, A study of the length-weight relationship, condition factor and age of ten fish species from the lower Nun River. Niger Delta. Niger Delta. Afr. J. Appl. Z. Zool. Environ. Biol. 9 (2007).13-19.

[16] D. Pauly, Linear regressions in fisheries research, Journal of the Fisheries Research Board of Canada. 30 (1993) 409-434.

[17] R. Riedel, L.M. Caskey, S.H. Hurlbert, Length-weight relations and growth rates of dominant fishes of the Salton Sea: implications for predation by fish-eating birds. Lake and Reservoir Management. 23 (2007) 528-535.

[18] K.A. Ighwela, A.B. Ahmed, A.B. Abol-Munafi, Condition Factor as an Indicator of Growth and Feeding Intensity of Nile Tilapia Fingerlings (Oreochromis niloticus) Feed on Different Levels of Maltose American-Eurasian. American-Eurasian Journal of Agricultural and Environmental Science. 11(4) (2011) 559-563.

[19] H. Musa et al., Length Weight Relationship, Condition Factor and Stomach Contents Analysis of Oreochromis Niloticus in Shirmu Lake Hungu, Kano state, Nigeria. Global Advanced Research Journal of Agricultural Science. 5(7) (2016) 315-324.

[20] U.B. Iyabo, Length-Weight Relationship and Condition Factor of Chrysichthys nigrodigitatus (Lacepede: 1803) of Ebonyi River, South Eastern Nigeria. American Journal of Agricultural Science. 2(2) (2015).70-74.

[21] K.B. Olurin, O.A. Aderibigbe, Length-Weight Relationship and Condition Factor of Pond Reared Juvenile Oreochromis niloticus. Journal of Zoology. 1 (2006) 82-85.

[22] A.I. Payne, R.C. Wakeford, E.T. Ndomahina, Fish distribution and zonation along, a tropical African river, the Rokel/Seli River, Sierra Leone, West Africa. Smithiana Bulletin. 12 (2010) 25-36.

[23] Naiman R.J., Latterell J.J., Principles for linking fish habitat to fisheries management and conservation, 2005.

[24] A.Kamdem-Toham, G.G. Teugels, First data on an index of Biotic Integrity (IBI) based on fish assemblages for the assessment of the impact of deforestation in a tropical West-African river. Hydrobiologia. 397 (1999) 29-38. 
[25] J.E. Beyer, On length-weight relationships computing the mean weight of the fish of a given length class. Fishbyte. 5(1) (1987) 1-3

[26] R.S. Tebiera de Mello, The condition factor of fish from two river basins in Sao Paulo, Brazil. Acta Scienta Maringa. 24 (3) (2006) 14-18.

[27] M. King, Fisheries Biology, assessment and management. 2nd edition, Blackwell Scientific Publications, Oxford, 2007, pp. 189-192.

[28] E.D. Le Cren, The length-weight relationship and seasonal cycle in gonad weight and condition in perch (Perca fluviatilis). The Journal of Animal Ecology. 20 (1951) 201-219.

[29] T.B. Bagenal, F.W. Tesch, Methods for assessment of fish production in freshwaters. Oxford, Blackwell Scientific Publication, 1978, pp. 350.

[30] A.I. Payne, The ecology, distribution and diversity of fish species in Sierra Leone rivers and response to human impacts, Environmental biology of fishes. 101(5) (2018) 843-864.

[31] J. Daget, Les poissons du Fouta Dialon et de la Basse Guineé. Mémoires de l'Institut Francaise d'Afrique Noire No. 65 (1962) 1-20.

[32] J. Daget, A. Iltis, Poissons de Cote d'Ivoir (eaux douce et saumatre). Mémoires de l'Institut Francaise d'Afrique Noire, No. 74 (1965) 1-385.

[33] R.H. Lowe-McConnell, Fish Communities in Tropical Freshwaters: Their Distribution Ecology and Evolution. Longman. London, 1975, pp. 337.

[34] C. Leveque, D. Paugy, Les poissons des eaux continentals africaines. IRD, Paris, 1999, $521 \mathrm{pp}$.

[35] R. Abell et al., Freshwater Eco regions of the world: a new map of biogeographic units for freshwater biodiversity conservation. BioScience. 58(5) (2008) 403-414.

[36] G.W. Ssentengo, M. Ansa-Emmin, Marine Fishery Resources of Sierra Leone: A Review of Exploited Stocks. FAO CECAF/ECAF Ser. 86/34, 1986, 67 pp.

[37] A.I. Payne, R.A. Wakeford, A Guide to the Fish Species of the Rokel/Seli River in Sierra Leone (MRAG), 2007.

[38] D. Paugy, C. Leveque, G.G. Teugels, The Fresh water and Brackish Water fishes of West Africa. IRD, Paris, MRAC, Tervuren. 2 vols., 2004, pp. 1272.

[39] A. Malik et al., Length-weight Relationship and Condition Factor of Red Tilapia (Hybrid) Reared in Cemented Tanks of Sun-bright Red Tilapia and Ornamental Hatchery-Karachi, Sindh-Pakistan. Sindh University Research Journal-SURJ (Science Series). 49(1) (2017) 159162.

[40] Environmental Protection (Water) Policy, Monitoring and Sampling Manual Biological assessment, 2018.

[41] R.O. Anderson, S.S. Gutreuter, Length-weight relationship and associated indices. American Fisheries Society, 1985, pp. 283-300.

[42] S. Nandlal, T. Pickering, Tilapia fish farming in Pacific Island countries. Volume 1. Tilapia hatchery operation. Noumea, New Caledonia: Secretariat of the Pacific Community, 2004.

[43] D. Pauly, Some simple methods for the assessment of tropical fish stocks. FAO Fisheries Technical paper, (234), FAO, Rome, Italy, 1983, pp. 52.

[44] L.M. Gomiero, F.M.S. Braga, The condition factor of fishes from two river basins in Sao Paulo state, Southeast of Brazil. Acta Scientiarum. 27 (2005) 73-78. 
[45] M. Lizama, A.P. De los, A.M. Ambrósio, Condition factor in nine species of fish of the characidae family in the upper paraná river floodplain, Brazil. Brazilian Journal of Biology. 62 (2002). 113-124.

[46] E.O Ahmed, M.E. Ali, A.A. Aziz, Length-weight Relationships and Condition factors of six fish species in Atbara River and Khashm elgirba Reservoir, Sudan. International Journal of Agriculture Sciences. 3(1) (2011) 65-70.

[47] A.S. Dan-Kishiya, Length-weight relationship and condition factor of five fish species from a tropical water supply reservoir in Abuja, Nigeria. American Journal of Research Communication. 1 (2013). 175-187.

[48] R. Riedel, L.M. Caskey, S.H. Hurlbert, Length-weight relations and growth rates of dominant fishes of the Salton Sea: implications for predation by fish-eating birds. Lake and Reservoir Management, 2007, 23:528-535.

[49] R.C. Viadero, Factors Affecting Fish Growth and Production, 2005.

[50] A.K. Suman et al., Assessment of water quality and fish growth in micro-water sheds of Banswara District in Southern Rajasthan. 1 (2017) 111-120.

[51] R.D. Zweig, J.D. Morton, M.M. Stewart, Source Water Quality for Aquaculture. The World Bank, Washington, DC. 1999.

[52] J. E. G. Parra, B. Baldisserotto, Effect of water $\mathrm{pH}$ and hardness on survival and growth of freshwater teleosts. Fish Osmoregulation. (2007) 135-150.

[53] I.O. Elegbede et al., Effect of Water Quality Characteristics on Fish Population of the Lake Volta, Ghana. Journal of Environmental \& Analytical Toxicology. 5 (2015) 317.

[54] G.U. Ahmed et al., Growth and Production Performance of Monosex Tilapia (Oreochromis niloticus) Fed with Homemade Feed in Earthen Mini Ponds. Pak. J. Biol. Sci. (23) (2013) 1781-1785.

[55] R. Hile, Age and growth of cisco Leucicthyes artedi le Suercur in the lake of north eastern highland. 48 (1936) 211-314.

[56] W.R. Martin, The mechanics of environmental control of body form in fishes. Univ. Toronto. 58 (1949) 1-91.

[57] T.B. Bagenal, F.W. Tesch, Methods for assessment of fish production in freshwaters. Oxford, Blackwell Scientific Publication, 1978, pp. 350.

[58] U. Bala et al., Study of ichtyofauna of Daberam reservoir in Katsina State. Bayero Journal of Pure and Applied Sciences. 2(2) (2009) 172-174.

[59] P.E. Ndimele et al., Length-weight relationship, condition factor and dietary composition of Sarotherodon melanotheron, Ruppell, 1852 (Pisces: Cichlidae) in Ologe Lagoon, Lagos, Nigeria. Agriculture and Biology Journal of North America. 1(4) (2010) 584-590.

[60] A. Anene, Condition factor of four cichlid species of a man-made lake in Imo State, Southeastern Nigeria. Turkish Journal of Fisheries and Aquatic Sciences. 60 (2005) 215-230.

[61] A.A. Ayoade, Length-Weight Relationship and Diet of African Carp Labeo ogunensis (Boulenger, 1910) in Asejire Lake Southwestern Nigeria, Journal of Fisheries and Aquatic Science. 6(4) (2011) 472-478.

[62] A.I. Eleshinnia, S.O. Olufeagba, R. Aminu, Effects of some environmental factors on the fecundity of tilapia species (family cichlidae) in Kigera Reservoir New Bussa, 2005, pp. 863. 
[63] J.F.N. Abowei, The Condition Factor, Length-Weight Relationship and Abundance of Ilisha Africana (Block, 1795) from Nkoro River Niger Delta, Nigeria. Advance Journal of Food Science and Technology. 2(1) (2010) 6-11.

[64] R.H. Lowe, The breeding behavious of tilapia species (Pisces: Cichlidae) in natural waters: observations on T. Karomo Poll and T. variabilis Booulenger, Behaviour. 9(1) (1956) 140162.

[65] M.B. Timmons et al., Recirculating Aquaculture Systems, 2nd Edition. Cayuga Aqua Ventures, Ithaca, NY 14850, USA. NRAC Publication No. 01-002, 2002, pp. 800. 